\title{
NOTE ON THE INSCRIPTION OF THE MAUSOLEUM FRIEZE.
}

THE inscription (Fig. 1) on block $1010^{1}$ of the Amazon Frieze of the Mausoleum has hitherto been regarded as illegible. ${ }^{2}$ The letters are $03 \mathrm{~m}$. high and carefully cut in three lines across the shield of one of the combatants, but have been (perhaps wilfully) defaced. The block in question is one of the twelve acquired by the exertions of Stratford de Redcliffe in 1846 from the Knights Hospitallers' Castle of S. Peter at Budrum. Of the twelve blocks three were built into the seaward wall of the castle with the arms and inscription (1506) of the Captain Constantius de Opertis: ${ }^{3}$ the remaining nine, of which No. 1010 is one, were placed inside Newton's 'third gate,' five in the seaward tower and four immediately opposite. Their position is shewn in the drawing of Luigi Mayer," where No. 1010 is recognisable in the upper left-hand block of the four on the left side of the picture.

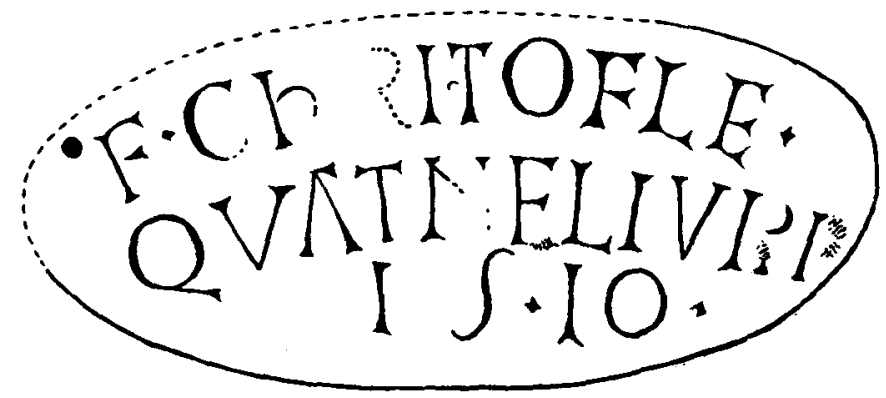

Fif. 1.-Ixscription ox the Mausoleum Frieze.

The inscription reads :-

$$
\begin{aligned}
& \text { F(rater) Christofle } \\
& \text { Quatnel, Jul(ii) 1, }
\end{aligned}
$$

1510.

\footnotetext{
${ }^{1}$ B. M. Catal. Gr. Scullp. ii. 103 ; illustrated in R. Dalton's series of engravings (1751-2), W. M. Devereux, Views on the shores of the Mediterranean (1847), Pl. XVI., Mon. dell' Inst. v. Pl. XIX. (iii.)

2 Newton in Class. MIus. v. 185.

3 J. H. Allan, Pictorial Tour, p. 39.
}

* Vievs in the Ottoman Empire. chiefty Caramania (1803), engraved again with the figures altered in Ionian Antiquities Vol. ii. Supp. P1. II. and signed Myers (sic) delint : Devereux remarks that the drawing is exceed. ingly unreliable, having probably been made up of sketches taken from a boat. 
The knight referred to is very probably Christoph Waldener of the Tongue of Germany, Castellan of Rhodes in 1522,5 who distinguished himself at the head of his nation in the siege of the same year. ${ }^{6}$ The faulty spelling may be due to the strangeness of German and English names to a southern ear. 7

Of Waldener's connexion with the fortress nothing further is known, ${ }^{8}$ but it is interesting to remark that the supervision of the Castle of S. Peter, which was built in the first place by a German (Heinrich Schlegelholt), was entrusted in 1428 to the Grand Bailly of Germany, who was expected to visit it once a year and to be responsible for its repair and armament. ${ }^{9}$ Waldener may thus have been captain in $1510,{ }^{10}$ or merely visitor.

F. W. Hasluck.

P.S.-Mr. G. F. Hill reads IVRII in 1. 2, and suggests that a title may be the solution. I have since examined the stone again, but cannot convince myself, and doubt whether certainty is possible as to this badly-used passage of the inscription. A possibility not to be overlooked is that the whole of 1. 2 (there is no stop after 'Quatnel' and they are lavished elsewhere) is occupied by the name, either of Waldener in a new and wonderful form, or of a person unknown to us.

F. W. H.

5 Bosio ii. 538.

6 ibid. 563.

- Waldener himself figures as Vualderic in Fontanus (Bell. Rhor. (1527) ii.). Heinrich Schlegelholt is called Essone di Slegleoltz by Bosio and some English Knight is disguised by the same author under the extraordinary name of Sequipunt.

${ }^{8}$ Fontanus (loc. cit.) describes him as Germanus eques armorum et navigandi peritus urbisque imperialis Hagenau summus praefectus ac Commendator qui Rhodiis in pace jus aicelat. Gonssancourt (ii. 538) says he died in 1533.
The supposed. Waldener arms in the Castellania at Rhodes given by Berg are really, as Belabre has recoguised, those of L'Isle Adam : the building dates from the reign of $G$. M. d'Amboise (1503-12), before Waldener became Castellan.

9 Bosio ii. 147 (1428), 148 (1443), but cf. 481 (1501), where the new works at S. Peter's are visited by the Prior of Aquitaine.

${ }^{10}$ A list of Captains of S. Peter is given in Newton's Halicarnassus ii. 2. 665, Note 9, but many names can be added from Bosio. 